\title{
JAMES BAILEY
}

The

Metrical and Rhythmical Typology

of K. K. Slučevskij's Poetry

LISSE

THE PETER DE RIDDER PRESS

1975 
(c) Copyright reserved

No part of this book may be translated or reproduced in

any form, by print, photoprint, microfilm, or any other means

without written permission from the author.

ISBN 9031600512

The text of this article is reprinted from

INTERNATIONAL JOURNAL OF SLAVIC LINGUISTICS AND POETICS

XVIII (1975), pp. 93-117

Printed in The Netherlands 